\title{
Investigation of a Spinel-forming Cu-Mn Foam as an Oxygen Electrode Contact Material in a Solid Oxide Cell Single Repeating Unit
}

Zielke, Philipp; Wulff, Anders Christian; Sun, Xiufu; Jensen, Søren Højgaard; Kiebach, Wolff-Ragnar; Frandsen, Henrik Lund; Norby, Poul; Hagen, Anke

\section{Published in:}

Fuel Cells

Link to article, DOI:

$10.1002 /$ fuce.201700005

Publication date:

2017

Document Version

Peer reviewed version

Link back to DTU Orbit

Citation (APA):

Zielke, P., Wulff, A. C., Sun, X., Jensen, S. H., Kiebach, W-R., Frandsen, H. L., Norby, P., \& Hagen, A. (2017). Investigation of a Spinel-forming Cu-Mn Foam as an Oxygen Electrode Contact Material in a Solid Oxide Cell Single Repeating Unit. Fuel Cells, 17(5), 730-734. https://doi.org/10.1002/fuce.201700005

\section{General rights}

Copyright and moral rights for the publications made accessible in the public portal are retained by the authors and/or other copyright owners and it is a condition of accessing publications that users recognise and abide by the legal requirements associated with these rights.

- Users may download and print one copy of any publication from the public portal for the purpose of private study or research.

- You may not further distribute the material or use it for any profit-making activity or commercial gain

- You may freely distribute the URL identifying the publication in the public portal 
Investigation of a spinel-forming Cu-Mn foam as an oxygen electrode contact material in a solid oxide cell single repeating unit

\author{
P. Zielke*, A. C. Wulff, X. Sun, S. H. Jensen, R. Kiebach, H. L. Frandsen, P. Norby, A. Hagen \\ Technical University of Denmark, Department of Energy Conversion and Storage, Roskilde, Denmark \\ [*]Corresponding author: phzi@dtu.dk
}

\begin{abstract}
A critical issue in state-of-the-art solid oxide cell stacks is the contacting of the oxygen electrode. The commonly used ceramic contact layers are applied in a green state and cannot be sintered properly due to compliance limitations arising from other stack components like sealing glasses and steels. The consequence is a low layer and interface strength. A metallic copper manganese foam, which is oxidized under operation conditions into a conductive $\mathrm{Cu}_{1+\mathrm{x}} \mathrm{Mn}_{2-\mathrm{x}} \mathrm{O}_{4}$ spinel, is presented in this work as a viable contact solution. The foam has been electrochemically tested in a single repeating unit setup for 350 hours of constant operation, followed by dynamic conditions with thermal cycles. After operation, a micro structural analysis using scanning electron microscopy, energy dispersive X-ray spectroscopy and Xray diffraction was carried out. It was confirmed that after oxidation/operation the manganese solely formed a CuMnspinel phase, mixed with a $\mathrm{CuO}$ phase. A separate Mn-oxide phase was not found. The conductivity and contacting of the foam was sufficient for $>350$ h of SOFC operation. With an initial serial resistance comparable to single cell tests using gold foil as contact material and moderate degradation rates, the CuMn foam presented itself as an interesting cathode contact solution.
\end{abstract}

Key words: solid oxide cell; single repeating unit; cathode contact material; oxygen electrode contact material;

$\mathrm{Cu}_{1+\mathrm{x}} \mathrm{Mn}_{2-\mathrm{x}} \mathrm{O}_{4}$; SOC; SOFC; SOEC; fuel cell; $\mathrm{Cu}-\mathrm{Mn}$ foam

\title{
1 Introduction
}

One of the vital prerequisites for solid oxide cell (SOC) stacks, in fuel cell or electrolysis mode, is a well-established electrical contact between the cells' individual layers and interconnects, which persists over long operation periods and dynamic conditions, e.g. load and thermal cycling. One of the weakest interfaces and therefore the one most prone to loss of contact is between the oxygen electrode and the interconnect ${ }^{[1]}$. In single cell testing, excellent contacting can be achieved by using noble metals, like gold foils and meshes ${ }^{[2]}$, but these solutions are too costly to be applied in stack production. Instead, state-of-the-art SOC use green, i.e. not sintered, oxygen electrode-like ceramic contact layers ${ }^{[3,4]}$. These cannot be sintered fully after stack assembly, because the typically required high firing temperatures above 1000 ${ }^{\circ} \mathrm{C}^{[4]}$ are not compliant with other stack components like sealing glasses and steel interconnects. Consequently the 
oxygen electrode contact layer's full bulk and interface (to electrode and / or interconnect) strength cannot be achieved. One possible route to improve the interface strength are composite contact layers containing Si-based glasses ${ }^{[5]}$. Silicon species have however been reported to negatively affect the long-term stability of solid oxide cells ${ }^{[6]}$.

A different contacting approach is a more flexible, porous contact material, similar to the nickel mesh often applied on the fuel electrode. A recently developed metallic copper-manganese foam (Alantum Corp. / RIST, Korea) is a promising candidate. Under operation conditions (oxidizing atmosphere, temperatures around $700-800{ }^{\circ} \mathrm{C}$ ), the foam is oxidized to form an electrically conducting $\mathrm{Cu}_{1+\mathrm{x}} \mathrm{Mn}_{2-\mathrm{x}} \mathrm{O}_{4}$ spinel-phase. Though brittle, the porous structure is believed to be more compliant with small mechanical deformations that arise from temperature gradients and thermal cycling. The formed spinel itself is similar or identical to protective interconnect coatings ${ }^{[7-9]}$ and should therefore exhibit a sufficient long-term stability and form a stable interface to a spinel-coated interconnect. In a recent study by Szabo et al ${ }^{[10]}$ the $\mathrm{Cu}-\mathrm{Mn}$ foam was tested as an oxygen electrode contact material with rather unsatisfactory results, where Mnrich oxide scales had formed instead of the desired spinel phase. Electrochemical testing in fuel cell mode showed low performance not suitable for operation. Our investigation shows a different, much more promising result. Here we report, to the best of the authors' knowledge, for the first time a successful test of Cu-Mn foam as a SOC oxygen electrode contact material in a single repeating unit (SRU) setup.

\section{Experimental}

A planar anode supported solid oxide fuel cell with a size of $5 \mathrm{x} 5 \mathrm{~cm}^{2}$ was used in this study. The half-cell (without oxygen electrode) was supplied by Haldor Topsoe A/S. It consisted of a 300 $\mu$ m thick Ni-YSZ (yttria-stabilized zirconia) support layer, a Ni-YSZ fuel electrode (10-15 $\mu$ m thickness), a YSZ electrolyte (10-15 $\mu \mathrm{m})$ and a CGO (gadolinium doped ceria) barrier layer (5-10 $\mu \mathrm{m})$. A 4 x $4 \mathrm{~cm}^{2}$ LSC (lanthanum strontium cobaltite)-CGO oxygen electrode $(10-15 \mu \mathrm{m})$ was screen printed onto the barrier layer and subsequently sintered. No oxygen electrode contact layer was applied. The cell was inserted between two sheets of metallic contact material (anode side: nickel felt, 400 $\mu \mathrm{m}, \sim 80 \%$ porosity; cathode side: $\mathrm{Cu}-\mathrm{Mn}$ foam, Cu:Mn ratio 3:2, $700 \mu \mathrm{m}$ initial thickness, $87 \%$ initial porosity, pore size $\sim 450 \mu \mathrm{m}$, Alantum Corporation, Korea) and two metallic interconnects. Both interconnects were made from Crofer22 APU. The oxygen side interconnect was coated in-house on both sides with a $\mathrm{CoMn}_{2} \mathrm{O}_{4}$-spinel by electrophoretic deposition (EPD) ${ }^{[8]}$. The fuel side interconnect was coated with nickel oxide $(\mathrm{NiO})$ on the backside facing the steel current collector. The Cu-Mn foam was cold-rolled to $350 \mu \mathrm{m}$ thickness ( 74\% porosity in metallic state) prior to assembly. The Ni-felt was used as supplied. Crofer22 APU spacers were used to accommodate the contact materials between the cell and the interconnects. Cell, interconnects and frames were sealed using glass seals. 
The SRU test setup is shown in Figure 1. For further information see ${ }^{[11,12]}$. The SRU was heated up to $900{ }^{\circ} \mathrm{C}$ for sealing with $20 \mathrm{NL} / \mathrm{h}$ of $9 \% \mathrm{H}_{2}$ in $\mathrm{N}_{2}$ supplied to the fuel electrode and $40 \mathrm{NL} / \mathrm{h}$ of air supplied to the oxygen electrode. A weight load of $12 \mathrm{~kg}$ was applied to compress the seals and ensure gas tightness. The SRU was kept under these conditions for $2 \mathrm{~h}$. Afterwards it was cooled down to $850{ }^{\circ} \mathrm{C}$. The fuel electrode gas flow was changed to $24 \mathrm{NL} / \mathrm{h}$ of 4.2\% $\mathrm{H}_{2} \mathrm{O}$ in $\mathrm{H}_{2}$ and the air flow to the oxygen electrode was increased to $140 \mathrm{NL} / \mathrm{h}$. The SRU was left under these conditions for $6 \mathrm{~h}$ to fully reduce the Ni oxide in the anode and anode support. Afterwards an initial characterization with varying gas compositions was carried out at $850{ }^{\circ} \mathrm{C}, 800^{\circ} \mathrm{C}, 750{ }^{\circ} \mathrm{C}$, and $700{ }^{\circ} \mathrm{C}$ by measuring polarization (i-V)

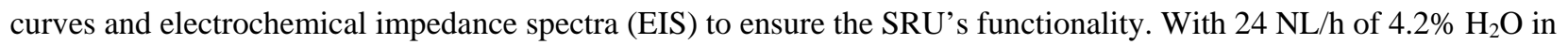
$\mathrm{H}_{2}$ to the fuel electrode and $140 \mathrm{NL} / \mathrm{h}$ of air to the oxygen electrode side, the SRU was operated under constant conditions for $350 \mathrm{~h}$ with a current density of $0.5 \mathrm{~A} / \mathrm{cm}^{2}$ at $700{ }^{\circ} \mathrm{C}$. EIS spectra with an amplitude of $60 \mathrm{~mA}$ were recorded every $10 \mathrm{~h}$ using a Solartron 1255 frequency analyzer and an external shunt. The spectra were recorded from $0.08 \mathrm{~Hz}$ to $82 \mathrm{kHz}$ with six points per decade. The impedance data were corrected using the short-circuit impedance response of the test set-up. From the recorded spectra the serial resistance $\mathrm{R}_{\mathrm{S}}$ (high frequency intercept) and polarization resistance $R_{P}$ (difference between low and high frequency intercept of the impedance curve) were extracted. The continuous test was followed by four thermal cycles, i.e. cooling the SRU down below $150{ }^{\circ} \mathrm{C}$ and heating to $700{ }^{\circ} \mathrm{C}$ with a cooling / heating rate of $1{ }^{\circ} \mathrm{C} / \mathrm{min}$. During the cycling, the oxygen electrode was supplied with $50 \mathrm{NL} / \mathrm{h}$ of air and the fuel electrode with $20 \mathrm{NL} / \mathrm{h}$ of $9 \% \mathrm{H}_{2}$ in $\mathrm{N}_{2}$. After each cycle, the SRU was characterized by measuring DC i-V curves and EIS spectra with varying gas compositions fed to the fuel and the oxygen electrode. Finally, the SRU was cooled down to room temperature at a rate of $1^{\circ} \mathrm{C} / \mathrm{min}$ with $50 \mathrm{NL} / \mathrm{h}$ of air supplied to the oxygen electrode and 20 $\mathrm{NL} / \mathrm{h}$ of $9 \% \mathrm{H}_{2}$ in $\mathrm{N}_{2}$ supplied to the fuel electrode. The SRU was disassembled and the oxidized contact foam was investigated by X-ray diffraction (XRD) and electron microscopy. The XRD data were collected using a Rigaku

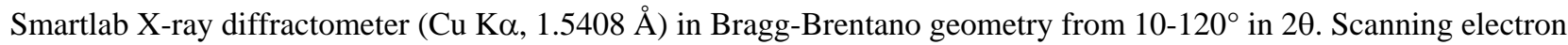
microscopy (SEM) was performed on a Zeiss 1540 XB microscope. Elemental mapping by energy-dispersive X-ray spectroscopy (EDS) was done using a Hitachi TM3000 microscope. The images were analyzed using the Image software ${ }^{[13]}$.

\section{Results and discussion}

\section{1 Electrochemical testing}

For the evaluation of the applicability of the $\mathrm{Cu}-\mathrm{Mn}$ foam as a contact material the open circuit voltage (OCV) and the serial resistance $\left(\mathrm{R}_{\mathrm{S}}\right)$ were considered. The first value is a direct indication of the gas tightness, determined by the gas 
composition and the temperature (Nernst equation). The second reflects the contacting and is mainly determined by the conductivity of the electrolyte. After the sealing, the initial OCV at $850{ }^{\circ} \mathrm{C}$ with dry hydrogen (fuel electrode: $24 \mathrm{NL} / \mathrm{h}$ of $\mathrm{H}_{2}$ ) and air (oxygen electrode: $140 \mathrm{NL} / \mathrm{h}$ of air) was $1188 \mathrm{mV}$. This corresponds to a water content of $0.4 \%$ and indicates an excellent gas tightness of the SRU. Before the constant operation at $700{ }^{\circ} \mathrm{C}$, an OCV of $1090 \mathrm{mV}$ and thus only $15 \mathrm{mV}$ lower than the theoretical Nernst potential, was measured, confirming the SRU's gas tightness. After operation under constant conditions and thermal cycling, the OCV remained at the same value. In addition, the behavior after $350 \mathrm{~h}$ of operation under constant conditions and thermal cycling was tested. Figure 2a shows the development of the cell voltage during the $350 \mathrm{~h}$ of operation under constant SOFC conditions at $700{ }^{\circ} \mathrm{C}$ and $0.5 \mathrm{~A} / \mathrm{cm}^{2}$. The nearly vertical features are caused by periodic EIS measurements. An obvious decrease of performance by $20 \mathrm{mV}$ was observed over this period. This degradation is as well reflected in the $\mathrm{i}-\mathrm{V}$ curves before and after the constant operation (Figure 2b).

The serial resistance is mainly determined by the ohmic resistance of the electrolyte, current constrictions in the electrodes and contact problems at the interfaces (within the cell and to the contact layers in the setup). The Rs-value at the beginning of the continuous operation of $238 \mathrm{~m} \Omega \mathrm{cm}^{2}$ correlates very well with a single cell test of an identical cell contacted with a standard oxygen electrode contact layer and a gold contact under comparable conditions (initial Rs: $230 \mathrm{~m} \Omega \mathrm{cm}^{2}$ ). This indicates a good contacting by the contact foam. During the $350 \mathrm{~h}$ of constant operation, $\mathrm{R}_{\mathrm{S}}$ increased with a rate of $10 \mathrm{~m} \Omega \mathrm{cm}^{2} / 1000 \mathrm{~h}$ to $242 \mathrm{~m} \Omega \mathrm{cm}^{2}$. It was accompanied by an increase of the polarization resistance $\mathrm{R}_{\mathrm{P}}$ of $52 \mathrm{~m} \Omega \mathrm{cm}^{2} / 1000 \mathrm{~h}$ (from $242 \mathrm{~m} \Omega \mathrm{cm}^{2}$ to $260 \mathrm{~m} \Omega \mathrm{cm}^{2}$ during $350 \mathrm{~h}$ ). The temporal development of $\mathrm{R}_{\mathrm{S}}$ and $\mathrm{R}_{\mathrm{P}}$ is shown in Figure 2c. With each thermal cycle, $\mathrm{R}_{\mathrm{S}}$ increased by approximately $10 \mathrm{~m} \Omega \mathrm{cm}^{2}$ (see Figure $2 \mathrm{~d}$ ). The observed changes of $R_{P}$ of $21,5,8$ and $-1 \mathrm{~m} \Omega \mathrm{cm}^{2}$ for the first, second, third and fourth thermal cycle respectively were less consistent with the changes of $\mathrm{R}_{\mathrm{s}}$.

The increasing serial resistance might be an indication of a worsening of the contact at one or more of the interfaces. However, to identify the origin of the increase of $\mathrm{R}_{\mathrm{S}}$, also the polarization resistance $\mathrm{R}_{\mathrm{P}}$ has to be considered. $\mathrm{A}$ localized loss of contact of the cell to the contacting/gas distribution layers would initially result in an increase of solely the $\mathrm{R}_{\mathrm{S}}$. In the presented test, $\mathrm{R}_{\mathrm{P}}$ increased during operation, which indicates a degradation of the electrode performance. Indications of a large area loss of contact influencing $\mathrm{R}_{\mathrm{P}}$ were not found during disassembly of the SRU nor are those expected in this kind of setup. The increase of $\mathrm{R}_{\mathrm{P}}$ can be attributed to the typically observed initial anode degradation ${ }^{[14]}$. The changes of $\mathrm{R}_{\mathrm{S}}$ and $\mathrm{R}_{\mathrm{P}}$ upon thermal cycling appear to be weakly correlated. Hence, it is likely that 
the cycling caused a certain loss of contact points. A more detailed analysis regarding which electrode or electrode process was degrading is needed, but was not the scope of this work.

\subsection{Microscopy}

Figure 3 shows the morphology of the foam before (metallic; a, b) and after operation (oxidized; c, d). The metallic foam exhibits a branched network with pores in the range of 400-500 $\mu \mathrm{m}$. The surface appears smooth with step like structures. Next to the branched network, porous, spherical particles in the size range up to $100 \mu \mathrm{m}$ were observed. EDS analysis (see Figure 4) identifies the spheres as manganese oxide particles deposited on a metallic Cu-Mn backbone structure. This is different from the material presented by Szabo et al. ${ }^{[10]}$, who reported a pure Cu backbone. After oxidation and operation in the SRU test, the branches showed a facetted surface structure. Some areas in the foam's uppermost layer (directly facing the oxygen electrode) show an increased surface roughness. These represent, most likely, the contact points between the foam and the oxygen electrode. A magnification of one of these contact point is presented in Figure 3d. From Figure 3c, the total contact area is estimated to be 5\% of the cell area. After operation, the spherical features were still present and a multitude of cracks had formed within the branched network. This could either have occurred during operation, thus explaining the observed $\mathrm{R}_{\mathrm{S}}$ increase, or be a result of disassembling the SRU. The spherical features are still present after operation. The EDS analysis shows that Cu has migrated into the Mn Oxide, resulting in a homogeneous distribution of $\mathrm{Cu}$ and $\mathrm{Mn}$ with an approximate ratio of 1:1. These findings are in line with the XRD results (see below).

\subsection{XRD analysis}

The Rietveld refinement of the diffraction pattern of the oxidized foam is shown in Figure 5. It clearly indicates, that the oxide foam consists of two phases, copper oxide (CuO, red tick marks, 34 wt\%) and a copper-manganese spinel $\left(\mathrm{Cu}_{1+\mathrm{x}} \mathrm{Mn}_{2-\mathrm{x}} \mathrm{O}_{4}\right.$, black tick marks, $\left.66 \mathrm{wt} \%\right)$. Considering the phase diagram of mixed copper-manganese oxides published by Driessens et al. ${ }^{[15]}$, this is to be expected. The unit cell parameters derived from the refinement indicate a close to 1:1 ratio of copper to manganese in the spinel $\left(\mathrm{Cu}_{1.5} \mathrm{Mn}_{1.5} \mathrm{O}_{4}\right)$. The $\mathrm{CuO}$ phase appears to be close to pure. This results in an overall molar composition of $67 \% \mathrm{Cu}$ and $33 \% \mathrm{Mn}$ and is in good agreement with the composition of the metallic foam of about 60:40 provided by the manufacturer. Our findings contradict the results obtained by Szabo et al. ${ }^{[10]}$, who reported Mn-rich oxide scales instead of a spinel phase.

\section{Conclusion}

A Cu-Mn foam contact solution for the oxygen electrode in a SOC single repeating unit setup was successfully tested in fuel cell operation. A slight increase of the serial resistance $R_{S}$ of $10 \mathrm{~m} \Omega \mathrm{cm}^{2} / 1000 \mathrm{~h}$ was observed during the $350 \mathrm{~h}$ test 
at a constant temperature of $700{ }^{\circ} \mathrm{C}$. It was accompanied by an increase of the polarization resistance $\mathrm{R}_{\mathrm{P}}$ of $52 \mathrm{~m} \Omega$ $\mathrm{cm}^{2} / 1000 \mathrm{~h}$ (mainly the typical initial anode degradation) and it is therefore possible that the $\mathrm{R}_{\mathrm{S}}$ increase is at least partially caused by a degradation of the electrode performance and not solely by a loss of contact. Upon thermal cycling a slight increase of $\mathrm{R}_{\mathrm{S}}$ of $\sim 10 \mathrm{~m} \Omega \mathrm{cm}^{2}$ per cycle was observed. The change of $\mathrm{R}_{\mathrm{P}}$ was less consistent and consequently less correlated to the $\mathrm{R}_{\mathrm{S}}$ increase. Hence, a loss of contact caused by thermal cycling was likely. After operation, SEM microscopy revealed multiple cracks in the branched structure of the foam that could have possibly caused the increased $\mathrm{R}_{\mathrm{S}}$ after thermal cycling. The XRD analysis of the oxidized foam confirmed, that the desired spinel $\mathrm{Cu}_{1+\mathrm{x}} \mathrm{Mn}_{2-\mathrm{x}} \mathrm{O}_{4} \mathrm{phase}$ besides a $\mathrm{CuO}$ phase, was formed.

The level of serial resistance increase during the constant operation indicates that the Cu-Mn foam is a promising candidate as oxygen electrode contact material, though the here measured degradation can be considered be too high for an industrial application. Additional tests in SOEC operation, with different electrode materials, long term studies and resistance measurements of the foam are still needed and will be carried out in the future.

\section{Acknowledgement}

The Alantum Corp., Korea is acknowledged for providing the Cu-Mn foam. Moreover the authors would like to thank Mr. H. Henriksen and Ms. P. H. Nielsen for technical assistance.

\section{References}

[1] D. N. Boccaccini, O. Sevecek, H. L. Frandsen, I. Dlouhy, S. Molin, M. Cannio, J. Hjelm, P. V. Hendriksen, Mater. Lett. 2016, 162, 250-253.

[2] S. H. Jensen, A. Hauch, P. V. Hendriksen, M. Mogensen, J. Electrochem. Soc. 2009, 156, B757.

[3] Z. Yang, G. Xia, P. Singh, J. W. Stevenson, J. Power Sources 2006, 155, 246-252.

[4] M. C. Tucker, L. Cheng, L. C. DeJonghe, J. Power Sources 2011, 196, 8313-8322.

[5] M. C. Tucker, L. Cheng, L. C. Dejonghe, J. Power Sources 2011, 196, 8435-8443.

[6] T. Horita, H. Kishimoto, K. Yamaji, M. E. Brito, Y. Xiong, H. Yokokawa, Y. Hori, I. Miyachi, J. Power Sources 2009, 193, 194-198.

[7] M. R. Bateni, P. Wei, X. Deng, A. Petric, Surf. Coatings Technol. 2007, 201, 4677-4684.

[8] F. Smeacetto, A. De Miranda, S. Cabanas Polo, S. Molin, D. Boccaccini, M. Salvo, A. R. Boccaccini, J. Power Sources 2015, 280, 379-386. 
[9] Z. Sun, S. Gopalan, U. B. Pal, S. N. Basu, Surf. Coat. Technol. 2016, DOI 10.1016/j.surfcoat.2016.09.028.

[10] P. Szabo, R. Costa, M. Park, B. Kim, I. Lee, Proc. 12th Eur. SOFC SOE Forum 2016, B0629.

[11] X. Sun, M. Chen, Y.-L. Liu, P. Hjalmarsson, S. D. Ebbesen, S. H. Jensen, M. B. Mogensen, P. V. Hendriksen, J. Electrochem. Soc. 2013, 160, F1074-F1080.

[12] R. Kiebach, K. Engelbrecht, L. Grahl-Madsen, B. Sieborg, M. Chen, J. Hjelm, K. Norrman, C. Chatzichristodoulou, P. V. Hendriksen, J. Power Sources 2016, 315, 339-350.

[13] C. a Schneider, W. S. Rasband, K. W. Eliceiri, Nat. Methods 2012, 9, 671-675.

[14] A. Hauch, M. Mogensen, A. Hagen, Solid State Ionics 2011, 192, 547-551.

[15] F. C. M. Driessens, G. D. Rieck, Zeitschrift für Anorg. und Allg. Chemie 1967, 351, 48-62.

\section{Figure Captions}

Figure 1: Sketch of the SRU setup using the Cu-Mn foam as oxygen electrode contact material.

Figure 2: Electrochemical performance; a) temporal development of the cell voltage during 350 h of SOFC operation under constant conditions; b) polarization (i-V) curves before testing, after $350 \mathrm{~h}$ of constant operation and after each thermal cycle; c) $R_{S}$ and $R_{P}$ during 350 h of operation under constant conditions; d) $R_{S}$ before and after each thermal cycle (24 NL/h 4\% $\mathrm{H}_{2} \mathrm{O}$ in $\mathrm{H}_{2}$ under OCV).

Figure 3: SEM images of the Cu-Mn foam; a) and b): metallic state; c) and d): after oxidation and operation in SRU setup.

Figure 4: EDS elemental mapping of the metallic foam; a) Cu map; b) O map; c) Mn map; d) overlay of $\mathrm{Cu}, \mathrm{Mn}$ and $\mathrm{O}$ maps.

Figure 5: Difference plot after Rietveld refinement of $\mathrm{MnCuO}_{\mathrm{x}}$. Measured (crosses) calculated (green solid line) and difference (purple) diffraction profiles. Tick marks show the position of the reflections from $\mathrm{Cu}_{1+\mathrm{x}} \mathrm{Mn}_{2-\mathrm{x}} \mathrm{O}_{4}\left(\mathrm{lower}_{\text {, black }}\right.$ tick marks) and $\mathrm{CuO}$ (upper, red tick marks). 
Figure 1

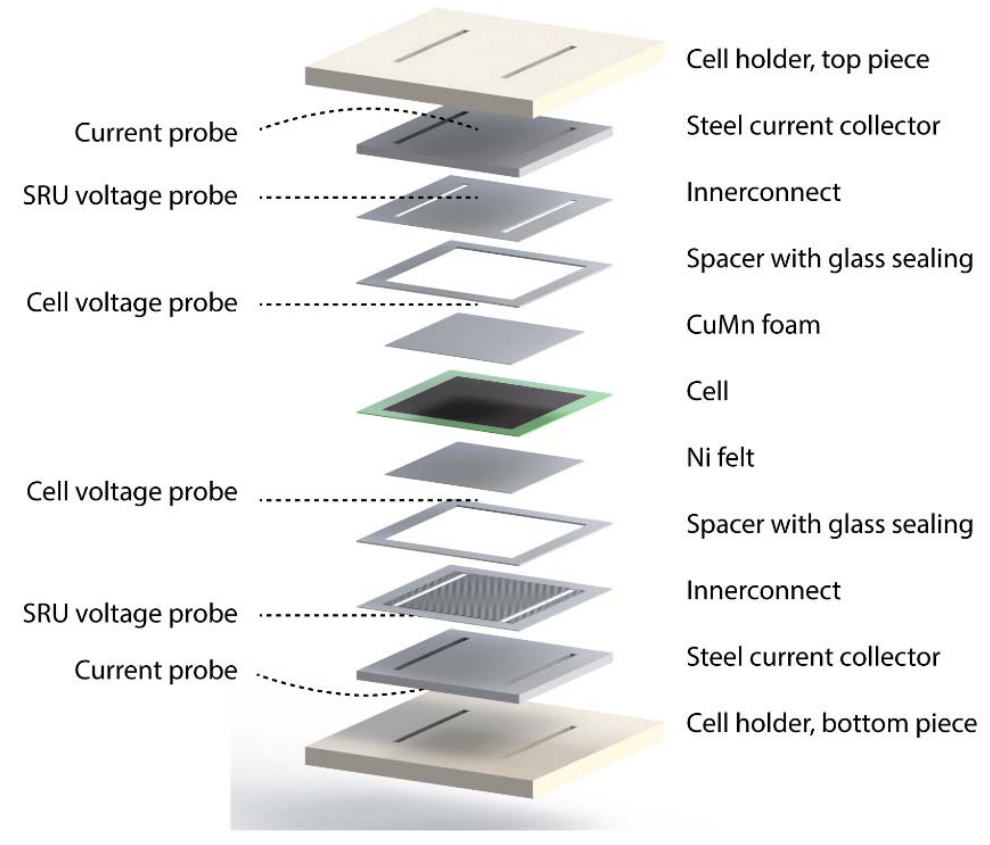

Figure 2
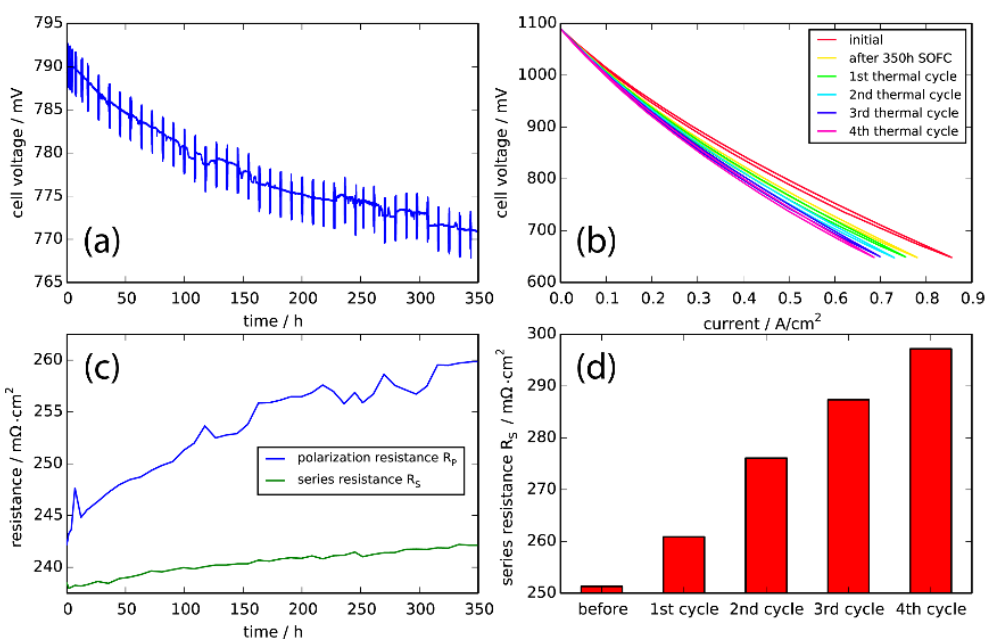
Figure 3
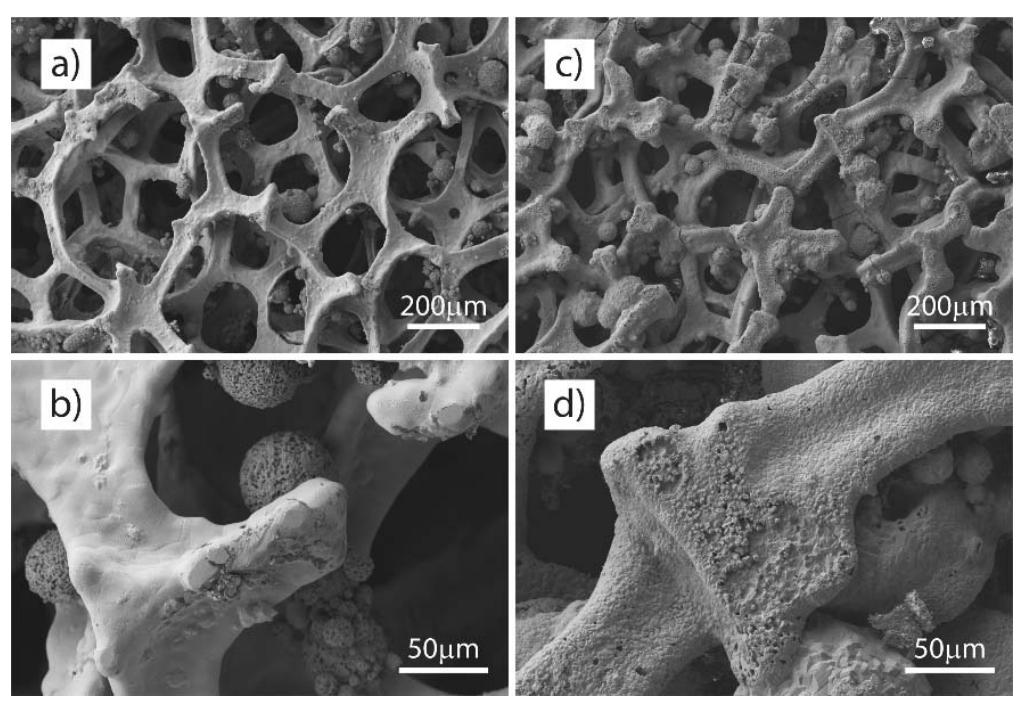

Figure 4

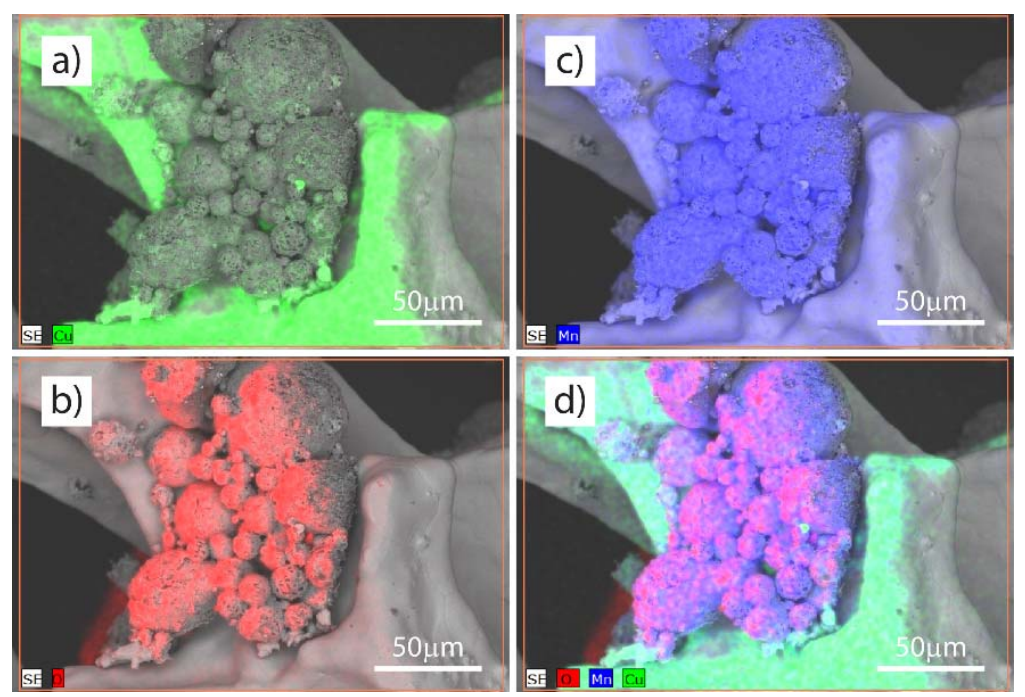


Figure 5

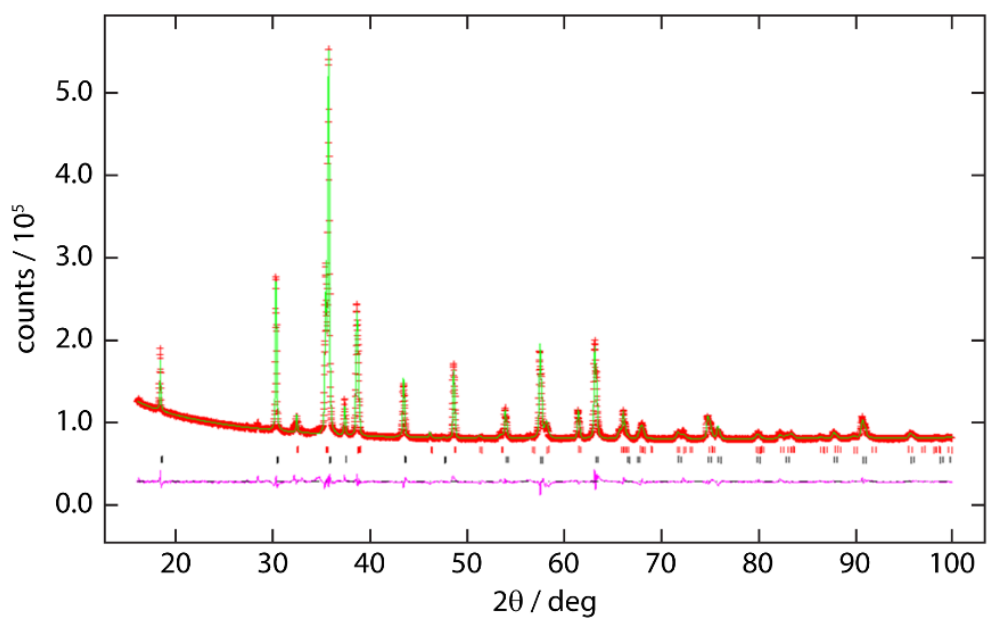

